\title{
The intention of South Africans to engage in collaborative consumption: The case of Uber
}

\begin{tabular}{|c|c|}
\hline $\begin{array}{l}\text { Authors: } \\
\text { Adele Berndt }{ }^{1,} \\
\text { Anmar Pretori } \\
\text { Derick Blaauw }\end{array}$ & (1) \\
\hline $\begin{array}{l}\text { Affiliations: } \\
{ }^{1} \text { Media, Mana } \\
\text { Transformatio } \\
\text { Jönköping Inte } \\
\text { Business Scho } \\
\text { University, Jön } \\
\text { Sweden }\end{array}$ & $\begin{array}{l}\text { sement and } \\
\text { Centre, } \\
\text { rnational } \\
\text { l, Jönköping } \\
\text { köping, }\end{array}$ \\
\hline $\begin{array}{l}{ }^{2} \text { Gordon Instit } \\
\text { Science, Unive } \\
\text { Pretoria, Preto } \\
\text { South Africa }\end{array}$ & $\begin{array}{l}\text { tte of Business } \\
\text { rsity of } \\
\text { ria, }\end{array}$ \\
\hline $\begin{array}{l}{ }^{3} \text { School of Eco } \\
\text { Sciences, Facu } \\
\text { and Managem } \\
\text { North-West U } \\
\text { Potchefstroom }\end{array}$ & $\begin{array}{l}\text { nomic } \\
\text { ty of Economic } \\
\text { ent Sciences, } \\
\text { iversity, } \\
\text {, South Africa }\end{array}$ \\
\hline $\begin{array}{l}\text { Correspondin } \\
\text { Derick Blaauw } \\
\text { derick.blaauw }\end{array}$ & $\begin{array}{l}\text { author: } \\
\text { @nwu.ac.za }\end{array}$ \\
\hline $\begin{array}{l}\text { Dates: } \\
\text { Received: } 25 \\
\text { Accepted: } 04 \\
\text { Published: } 14\end{array}$ & $\begin{array}{l}\text { May } 2021 \\
\text { ug. } 2021 \\
\text { Sept. } 2021\end{array}$ \\
\hline $\begin{array}{l}\text { How to cite th } \\
\text { Berndt, A., Pre } \\
\text { Blaauw, D., } 20 \\
\text { intention of Sc } \\
\text { engage in colla } \\
\text { consumption: } \\
\text { Uber', Acta Co } \\
\text { a961. https:// } \\
\text { org/10.4102/a }\end{array}$ & $\begin{array}{l}\text { is article: } \\
\text { torius, A. \& } \\
1 \text {, 'The } \\
\text { uth Africans to } \\
\text { borative } \\
\text { The case of } \\
\text { nmercii } 21(1) \text {, } \\
\text { loi. } \\
\text { c.v21i1.961 }\end{array}$ \\
\hline $\begin{array}{l}\text { Copyright: } \\
\text { (C) 2021. The A } \\
\text { Licensee: AOS } \\
\text { is licensed unc } \\
\text { Creative Comn } \\
\text { Attribution Lic }\end{array}$ & $\begin{array}{l}\text { uthors. } \\
\text { S. This work } \\
\text { er the } \\
\text { ions } \\
\text { ense. }\end{array}$ \\
\hline Read online: & \\
\hline 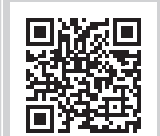 & $\begin{array}{l}\text { Scan this QR } \\
\text { code with your } \\
\text { smart phone or } \\
\text { mobile device } \\
\text { to read online. }\end{array}$ \\
\hline
\end{tabular}

Orientation: The idea of collaborative consumption is developing among consumers, where underutilised or excess resources, skills and money are shared among peers for compensation. Collaborative consumption involves sharing, and as such, Uber, an app-based transport service enables those with spare vehicle capacity to provide a fee-based transport solution.

Research purpose: This study investigates the intention to use this service in a South African context, specifically through the Technology Acceptance Model (TAM) and Theory of Planned Behaviour (TPB) because of the suitability of these models in this context. Differences between regular and seldom users are also examined.

Motivation for the study: With the widespread use of Uber in South Africa, understanding the factors contributing to the intention to use Uber requires examination.

Research design, approach and method: Data were collected using a quantitative survey among panel respondents of South Africans, using electronic data collection. The research instrument comprised pre-existing items measured on a 6-point Likert scale. A total of 367 usable responses were received. Data analysis included testing for differences in means (t-test, Satterthwaite-Welch t-test, Anova F-test, Welch F-test) as well as regression analysis (by means of multiple regressions and two-stage least squares).

Main findings: The findings indicate that South Africans intend to use the service largely due to their positive attitude towards the service, the perceived usefulness (PU) of the app and perceived behavioural (PB) control associated with the service. The value of the app has been highlighted in this research, and the importance of its functioning is evident.

Practical/managerial implications: The importance of providing a positive service experience impacts the intention to use the service in the future. This emphasises the importance of the service itself and the functioning of the app.

Contribution/value-add: Understanding the intention to use this service enables further development of this app and associated services.

Keywords: collaborative consumption; attitudes; TAM; TPB; intentions; Uber.

\section{Introduction}

Transport in South Africa is a very complex issue. Access to and ownership of a motor vehicle provides status to the user and is regarded as a necessity because of the dearth of public transport (Henama \& Sifolo 2017; Van Der Westhuizen 2007). However, factors such as cost, convenience and enforcement of drunken-driving legislation have resulted in more consumers intending to use other transport alternatives. Vehicles have been perceived as underutilised resources (Belk 2007), which encourages sharing of this resource with others (Weatherhead 2014; Zervas, Proserpio \& Byers 2017). In this context, a ride-sharing solution can be regarded as one of these alternatives.

The sharing economy, or peer-to-peer-based sharing, is a phenomenon that allows individuals to profit from underutilised assets (PricewaterhouseCoopers 2015). The sharing economy has grown as a result of several factors (Orabi 2019). These include inter alia: technological developments, decreases in purchasing power rising levels of urbanisation in most countries as well as stringent environmental regulations that promote principles of sustainability (Orabi 2019). The sharing economy, therefore, received growing attention from researchers in the last decade (Shereni 2019).

Through information and communication technology (ICT)-enabled platforms, both market and non-market activities (such as lending, sharing, renting and selling) are facilitated (Davidson, Habibi \& Laroche 2018; Laurell \& Sandström 2017). Collaborative consumption 
(CC) comes about when goods, services, solutions or money are shared among people linked to compensation (Möhlmann 2015). Examples of these services are found in different sectors, including media and entertainment (Spotify), hospitality (Airbnb), retail (Poshmark) and transport (Uber and Lyft) (PricewaterhouseCoopers 2015). Uber is an app-based transport service, with the app being integral to using the service. It is an example of CC as spare vehicle capacity is shared with others (Zervas et al. 2017). Uber employs 'unused personal automobiles [and] a large pool of potential drivers' by linking them to 'a digital ecosystem' to address a mobility issue among consumers (Spiegel 2016). Sharing allows this resource to be used, and this use occurs through the Internet (Belk 2014).

Although being a relative newcomer to the continent, Uber views Africa as a growth market (Van Zyl 2016), with the intention to treat this market as important. Uber has been active in South Africa since September 2013 with more than 4000 Uber drives - of which 2500 are in Gauteng (Henama \& Sifolo 2017). Its entry into South Africa has seen widespread acceptance, with 2 million trips undertaken in the first 6 months of 2015 (Segev 2015). Locals and tourists have utilised Uber as a cost-effective and safe transport system given the limited public transport alternatives (Henama \& Sifolo 2017). While car ownership can be considered 'culturally ingrained' (Van Der Westhuizen 2007:336) within South Africa, increasing use of other forms of transportation, including public transport and CC services such as Uber have been recorded.

Understanding purchase intention has been a focus in marketing studies because of its link with behaviour, and intention can be predicted based on the attitudes towards a specific behaviour (Ajzen 1991, 2011). The Technology Acceptance Model (TAM) (Davis 1989) has been widely used to determine the acceptance of new technology (Mathieson 1991; Taylor \& Todd 1995; Venkatesh 2000), including in South Africa (Averweg 2008), and the Theory of Planned Behaviour (TPB) (Ajzen 1985, 1991, 2011; Ajzen \& Fishbein 2005) has been widely used to investigate purchase intention (Ajzen 2011). Studies using TAM have focused on the adoption of computer technologies and services (Al-Gahtani, Hubona \& Wang 2007; Taylor \& Todd 1995; Yang 2013), while TPB has focused on both products (Chen 2007; Hamilton \& Terblanche-Smit 2018; Tarkiainen \& Sundqvist 2005) and services, including online services (Bhattacherjee 2000; Chen, Fan \& Farn 2007; Giles et al. 2004; Wu \& Chen 2005), automated vehicles (Kaye et al. 2020) and apps (Yang 2013). Both models have been described as 'empirically strong' (Mathieson 1991:187) with their use in various countries and being associated with various types of technology-based products and services.

Sharing has not been widely studied (Belk 2010), and the intention to engage in CC has also lacked research attention (Hamari, Sjöklint \& Ukkonen 2016). Much research into the sharing economy has been at the organisational level, with fewer studies into 'individual-level studies' among users (Cheah et al. 2020:2) and specifically in developing economies (Hossain 2020).
The impact of technology and specifically apps suggests that the perceptions of this technology influence the intention to adopt technological developments, as seen in the TAM model (Davis 1989; Natarajan, Balasubramanian \& Kasilingam 2017). The TPB model identifies attitudes, subjective norm (SN) and perceived behavioural control (PBC) as antecedents of intention (Hamilton \& Terblanche-Smit 2018). This highlights the importance of intention as an individual is likely to act in accordance with their intentions (Liu et al. 2012), and they impact a range of behaviours (Oliveira, Tomar \& Tam 2020; Sheeran 2002), which could be impacted by demographic variables. Thus, given the importance of intentions, the purpose of this research is to investigate the intention of South Africans to use CC, specifically Uber.

The main aim and contribution of this study are to determine the appropriateness of these models in the CC context and also as they apply to ride-sharing solutions therefore specifically understanding consumer choices in this regard. The developing market perspective on these services has largely been neglected (Hossain 2020); thus this research allows for a unique perspective of $\mathrm{CC}$ in the context of a developing market and specifically in South Africa. The intention to engage and support these sharing models impacts the income of a range of people (e.g. drivers) as well as the local and national economy (Zervas et al. 2017). The intentions underlying this form of consumption are currently unclear, and the effect of societal norms and expertise in the adoption of this technology is currently unknown. Differences in the constructs between regular and seldom users are also examined - as this can provide further insight into the main drivers of CC.

Another contribution of our study is the size and representativity of the research sample. Our study includes 367 respondents compared to just more than 300 respondents of the South African study done by Giddy (2019). This sample in the Giddy (2019) study cannot be regarded as representative as the 308 respondents in the study consisted only of Facebook contacts, reflecting built-in selection bias in terms of connection to the author. Another South African study (Maziriri et al. 2020) interviewed 152 Uber users in Johannesburg as respondents. The significant increase in the number of respondents of the current study is therefore a significant contribution to the literature in the field.

The article commences by examining the theories associated with CC and the nature of both purchase intention and the TAM and TPB models. The study and the findings are then presented, and the article concludes by suggesting implications for other platforms and further research in the area.

\section{Literature review}

To understand Uber as an example of CC, the intentions associated with using this service must be investigated. This section starts by examining CC and then presents the models used in the study. 


\section{Collaborative consumption}

This technology has also affected ownership and the use of assets (Hamari et al. 2016), as assets can now be used without ownership (Belk 2013). In this context, CC has developed as an alternate form of consumption that implies that resources are distributed (or shared) for a fee (Belk 2014). It is viewed as a 'peer-to-peer activity of giving, obtaining or sharing access to goods and services' (Hamari et al. 2016:1). Belk (2014) viewed this consumption as temporary access to a product or service, which occurs through access to the Internet. The Internet serves as a platform that facilitates sharing that is not limited by location (Belk 2014; Botsman \& Rogers 2011). Reasons for engaging in CC include economic (lower costs), societal (increasing populations) and technological (smartphones) (Möhlmann 2015; Tussyadiah 2015). While there is agreement regarding the importance of the use of technology, because of the developmental nature of the field, clarity does not exist regarding the nature of sharing, the sharing economy and collaborative consumption and differences that exist between these terms (Laurell \& Sandström 2017).

\section{Uber as a case of collaborative consumption}

Using the services offered by approximately 4000 drivers, Uber South Africa transported over half a million consumers in its first 30 months of operation (Uber 2017). The use of Uber requires a customer to first download their app and register an account. When a customer wants to use the service, they open the app and indicate the desired destination. An estimated charge and waiting time will be generated. If these are acceptable, the use of the service can be confirmed, and the vehicle will be dispatched. The service enables underutilised vehicles to be used to transport people for a fee. This can contribute to reducing waste and enables passengers to be productive or to avoid prosecution for driving under the influence of alcohol (PricewaterhouseCoopers 2015).

These services have not been without controversy, and they have also affected other businesses. The controversy involves the service's legality and employment conditions, a situation not limited to South Africa (Naughton 2016). Issues have also arisen regarding the safety of both drivers and passengers; hence some contemporary authors have questioned whether consumers should use Uber (Sodha 2017). Uber has not substantially affected car sales in the short term, but car rental companies and taxi organisations have experienced significant declines in the demand for their services (Wallsten 2015), though the long-term impact is currently unclear (Naughton 2016). Opposition to Uber has come from the taxi industry, which views Uber as a competitor 'stealing their business' (Akoob 2017).

\section{The intention to engage in collaborative consumption}

Understanding consumption intentions is important to marketers because of the link between intention and future behaviour (Ajzen 2011), and this is also the case with CC (Tussyadiah 2015). Intentions reflect the motivational factors that impact a person's behaviour and reflect the amount of effort they are prepared to expend to perform the behaviour (Ajzen 1991). In general, the stronger the intentions, the more likely it is that the behaviour will occur (Ajzen 1991; Mathieson 1991), though other factors can also impact the behaviour (Ajzen 2011). Previous research concerning apps suggests that the intention to use an app will translate into actual use (Yang 2013).

\section{The Technology Acceptance Model}

The TAM (Davis 1989) is the most widely used model and has been developed to determine the acceptance of technology (Al-Maghrabi, Dennis \& Vaux Halliday 2011; Venkatesh 2000) by addressing two specific factors, namely perceived usefulness (PU) and perceived ease of use (PEU), as indicators of the intention to use a specific technology. Perceived usefulness refers to the extent to which a technology will help people in their job (Davis 1989) and in their life, while PEU refers to the extent to which a technology's use is 'free from effort' (Davis 1989:320). In the case of apps, PU is associated with the extent to which the app provides timely and customised information (Yang 2013). Technology that is perceived as being useful and easy to use results in its acceptance (Venkatesh 2000).

Criticism of this model has been linked to its relatively generic nature as it does not investigate specific aspects of the technology, neither does it examine actual use behaviour (Bouwman \& Van De Wijngaert 2009). A further criticism of this model is that it is unclear about the extent to which it gives an indication of actual behaviour and that other factors, such as self-efficacy may provide clearer insights into the adoption of technology (Bouwman \& Van De Wijngaert 2009). As it does not take other aspects of behaviour into account (Nysveen, Pedersen \& Thorbjørnsen 2005), the inclusion of social aspects and PBC has been recommended.

\section{The Theory of Planned Behaviour model}

The TPB is described as an intention-based model linked to several beliefs concerning intended behaviour (Bhattacherjee 2000). This model (Ajzen 1991, 2011) is derived from the Theory of Reasoned Action (Fishbein \& Ajzen 1975), which identifies three determinants of an intention (Ajzen 2011; Chen et al. 2007; Hamilton \& Terblanche-Smit 2018). Firstly, the attitude (ATT) or predisposition toward a behaviour, which refers to the overall evaluation of a product (Ajzen 1985), service or (in this case) app (Yang 2013).

Secondly, the subjective norm or social pressure to engage in the behaviour, which is based on the opinions of people who are close to the individual (Chen et al. 2007) and thus reflects normative expectations (Giles et al. 2004).

Thirdly, Perceived Behavioural Control, which refers to the extent to which a person believes they are in control of specific action. This is associated with how difficult or complicated a person perceives that action to be (Ajzen 1991; Francis et al. 2004; 
Taylor \& Todd 1995). This reflects an individual's confidence in carrying out the behaviour (Ajzen 1991) and is influenced by factors such as access to resources and knowledge.

\section{The model and hypotheses in the study}

The use of both models is necessary in the context of online services due to their nature that includes an online (or technology) component that is integral to the provision of the service. Thus, this study uses both the TAM and the TPB model in investigating consumer intentions, as both TAM and TPB serve as appropriate predictors of intentions (Mathieson 1991).

These models have been widely used to measure intention in a wide range of services (Chen et al. 2007; Giles et al. 2004; Lee, Xiong \& Hu 2012; Mathieson 1991; Taylor \& Todd 1995; Wu \& Chen 2005) and can thus be regarded as suitable in the case of Uber. Examples of these services include electronic tolling services (Chen et al. 2007), online brokerage services (Bhattacherjee 2000), online tax services (Wu \& Chen 2005) and IT software (Kim 2010; Mathieson 1991; Taylor \& Todd 1995).

Due to the importance of intentions to behavioural outcomes, understanding the factors contributing to the intention to engage in CC is necessary, and in the case of Uber (an appbased service), use of both these models is required, similar to other technology-based services (Bhattacherjee 2000; Chen et al. 2007), as reflected in Figure 1.

Two categories of hypotheses have been formulated, linked to the specific models, and are reflected in the model. Previous research has indicated the importance of PU as well

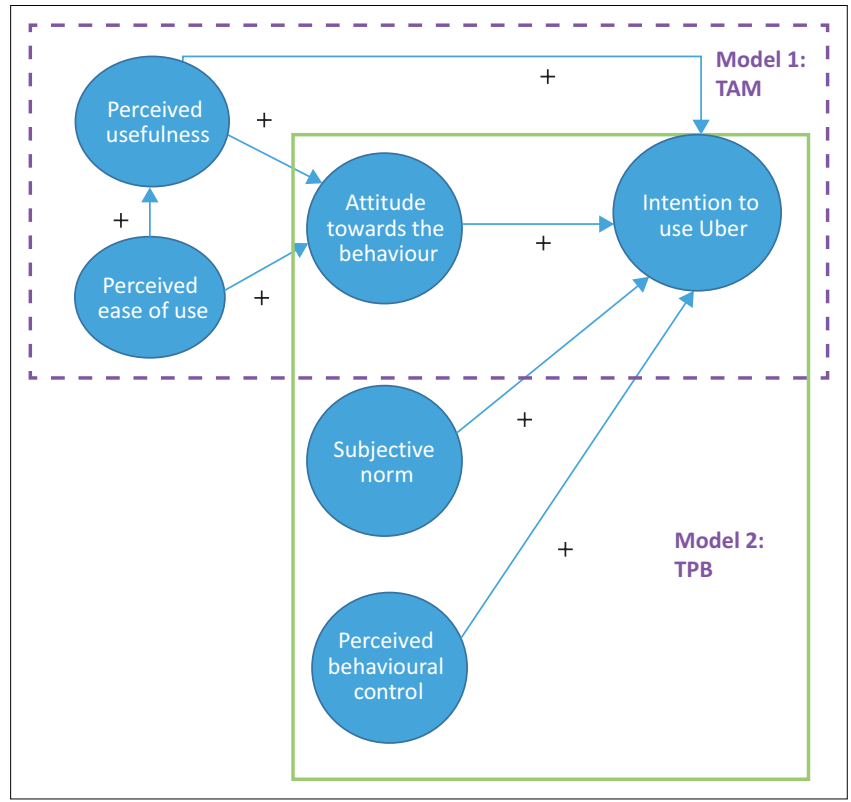

Source: Adapted from Chen, C.-D., Fan, Y.-W. \& Farn, C.-K., 2007, 'Predicting electronic toll collection service adoption: An integration of the Technology Acceptance Model and the theory of planned behavior', Transportation Research Part C: Emerging Technologies 15(5), 300-311. https://doi.org/10.1016/j.trc.2007.04.004

TAM, Technology Acceptance Model; TPB, Theory of Planned Behaviour.

FIGURE 1: The model used in the study. as PEU in understanding attitudes toward technological products (Chen et al. 2007; Taylor \& Todd 1995; Venkatesh 2000; Wu \& Chen 2005), resulting in the formulation of the following hypotheses.

PU indicates the usefulness of the technology and has previously been shown to positively influence attitudes towards a range of products and services (Cheah et al. 2020). As PEU reflects how uncomplicated a technology is to use, with ease of use influencing the customer technology preferences. Together, PU and PEU affect the overall attitude toward the technology, with positive PU and PEU resulting in a positive attitude. As Uber requires an app, the consumer must believe that the app (and the service) contributes positively to their life (PU) and is easy to use (PEU). This will then contribute to the development of a positive attitude and intention to use the technology. Thus, we hypothesise:

$\mathrm{H}_{1}$ : PU has a significant positive effect on the attitude toward using Uber, and

$\mathbf{H}_{2}$ : PEU has a positive effect on the attitude toward using Uber.

Further, PEU affects PU, with a relationship between these two variables (Natarajan et al. 2017), thus a positive evaluation of PEU influences the positive perception of PU (Chen et al. 2007; Wu \& Chen 2005). As the person perceives the Uber app as easy to use, they are will perceive it as useful, thus we propose:

$\mathbf{H}_{3}$ : PEU has a positive effect on the PU of Uber.

Perceived usefulness, while impacting the individual's attitude, also has a direct effect on customer intentions (Natarajan et al. 2017), though this can vary depending on the context and product category under investigation (source). Finding the Uber app as useful, we propose:

$\mathbf{H}_{4}$ : PU has a positive effect on the intention to use Uber.

In the case of model 2 (TPB), previous research has indicated a relationship between the three components in the TPB and the intention to carry out the behaviour. It is hypothesised that these individual components of TPB will positively affect the intention to use Uber, as provided below.

A positive (or favourable) attitude leads to a positive intention to engage in the behaviour (Liu et al. 2012) as seen in its potential impact on both intentions and actual behaviour (Ajzen 1987, 1991, 2011; Solomon et al. 2013). The more positive a person's attitude is towards a behaviour, the more likely that person is to behave in that way (Ajzen 1987). In the case of Uber, a positive attitude towards the service will be reflected in an intention to use the service. Thus, the following hypothesis has been formulated:

$\mathbf{H}_{5}$ : Attitude has a significant positive effect on the intention to use Uber.

The influence of people, as reflected in the SN, impacts the intention to engage in a behaviour (Liu et al. 2012). Subjective norm plays a significant role in explaining the intention to use e-commerce services (Bhattacherjee 2000; Yang 2013) as it 
is impacted by the desirability of the behaviour (Alam \& Sayuti 2011). In the case of Uber, SN is a relevant construct, and if important 'others' think a person should use the service, then that person will be more likely to do so. Thus, in this study, we propose:

$\mathbf{H}_{6}$ : Subjective norm has a positive effect on the intention to use Uber.

The ability to engage in a specific behaviour is determined by the perceived control over the behaviour and confidence in carrying out the behaviour (Alam \& Sayuti 2011). In the case of an app such as Uber, this includes both financial resources and access to a smartphone to register and use the app and the ability to pay for the service (Taylor \& Todd 1995; Yang 2013). If a person believes that they will be able to use the Uber service and that they have the necessary resources and skills, then the intention to use the service will increase. Thus, hypothesis 7 is formulated as follows:

$\mathbf{H}_{7}$ : PBC positively influences the intention to use Uber.

\section{Methodology}

\section{Research design, population, data collection and sampling}

As the purpose of the study was to investigate the intention of the South Africans to use Uber, a quantitative study was conducted using pre-existing scales associated with the two models. The population was defined as South Africans who were aware of Uber, and a filter question was used to determine this awareness. Those respondents who were not aware of Uber did not continue with the survey.

Consumer panels can provide a practical way to collect data as the provider has a clear picture of the nature of their panel members (Babin \& Zikmund 2015). Awareness of Uber was necessary to take part in the survey, and this served as a filter question to ensure that respondents were suitable to take part. A panel data collection organisation used their existing panels to distribute the electronic questionnaire throughout South Africa, resulting in a total of 367 usable responses, indicating the use of a convenience sample (Babin \& Zikmund 2015). Ethical issues were addressed through anonymity and confidentiality, with data being collected according to the principles of the General Data Protection Regulation (GDPR).

\section{Questionnaire design}

The survey consisted of two sections. Section A included demographic questions focused on gathering data concerning the respondent. Section B presented items associated with the TAM and TPB. The framework proposed by Francis et al. (2004) was used in the development of the TAM and TPB parts of the instrument as well as previous studies (Bhattacherjee 2000; Chen et al. 2007; Mathieson 1991; Taylor $\&$ Todd 1995). The internal reliability measurements from previous studies are provided in Table 1. The complete instrument appears in Appendix 1.
A 6-point Likert scale ( 1 = Strongly disagree; 6 = Strongly agree) containing three positive and three negative scale options that remove the midpoint (Chomeya 2010) was used. A filter question was inserted at the start of the questionnaire to ensure that if a respondent was unaware of Uber, they would be excluded from the study. Data analysis was conducted using SPSS 26, which included both univariate and multivariate analysis.

\section{Ethical considerations}

The article followed all ethical standards for carrying out research without direct contact with human or animal subjects. The data was collected anonymously and stored according to General Data Protection Regulations (GDPR).

\section{Findings}

\section{Sample characteristics}

Table 2 provides a summary of the basic demographic and socio-economic characteristics of the respondents in the sample. The majority $(56.7 \%)$ of the respondents were male, and $46.6 \%$ were aged between 25 and 34 years. The majority

TABLE 1: The instruments used in the study.

\begin{tabular}{llccc}
\hline Construct & Source & $\begin{array}{c}\text { Number of } \\
\text { items }\end{array}$ & & \multicolumn{2}{c}{ Internal reliability } \\
\cline { 4 - 5 } & & 6 & $\begin{array}{c}\text { Chen et al. } \\
\text { (2007) }\end{array}$ & $\begin{array}{c}\text { Taylor and Todd } \\
\text { (1995) }\end{array}$ \\
\hline PU & Chen et al. (2007) & 5 & $\alpha=0.93$ & $\alpha=0.68$ \\
PEU & $\begin{array}{l}\text { Bhattacherjee (2000) } \\
\text { Chen et al. (2007) }\end{array}$ & 5 & $\alpha=0.94$ & $\alpha=0.71$ \\
Attitude & $\begin{array}{l}\text { Taylor and Todd (1995) } \\
\text { Chen et al. (2007) }\end{array}$ & 6 & $\alpha=0.97$ & $\alpha=0.88$ \\
SN & $\begin{array}{l}\text { Taylor and Todd (1995) } \\
\text { Chen et al. (2007) }\end{array}$ & 6 & $\alpha=0.89$ & $\alpha=0.70$ \\
PBC & $\begin{array}{l}\text { Taylor and Todd (1995) } \\
\text { Chen et al. (2007) }\end{array}$ & 8 & $\alpha=0.96$ \\
\hline Intention & Chen et al. (2007) & 7 & $\alpha=0.97$ & $\alpha=0.91$ \\
\hline
\end{tabular}

$\mathrm{PU}$, perceived usefulness; $\mathrm{PEU}$, perceived ease of use; SN, subjective norm; PBC, perceived behavioural control.

TABLE 2: Demographic characteristics of the sample.

\begin{tabular}{lcccc}
\hline Characteristics & Frequency & $\%$ & Valid \% & Cumulative \% \\
\hline Gender & 152 & 41.4 & 41.4 & 41.4 \\
Female & 208 & 56.7 & 56.7 & 98.1 \\
Male & 7 & 1.9 & 1.9 & - \\
Prefer not to say & 367 & 100.0 & 100.0 & 100.0 \\
Total & & & & \\
Age & 17 & 4.6 & 4.6 & 4.6 \\
Younger than 25 & 171 & 46.6 & 46.6 & 51.2 \\
Between 25 and 34 & 155 & 42.2 & 42.2 & 93.5 \\
Between 35 and 44 & 14 & 3.8 & 3.8 & 97.3 \\
Between 45 and 54 & 3 & 0.8 & 0.8 & 98.1 \\
Older than 55 & 7 & 1.9 & 1.9 & - \\
Prefer not to say & 367 & 100.0 & 100.0 & 100.0 \\
Total & & & & \\
Primary occupation & 16 & 4.4 & 4.4 & 4.4 \\
Student & 301 & 82.0 & 82.0 & 86.4 \\
Employed (paid full time) & 31 & 8.4 & 8.4 & 94.8 \\
Pensioner/Retired & 8 & 2.2 & 2.2 & 97.0 \\
Self-employed & 4 & 1.1 & 1.1 & 98.1 \\
Unemployed & 7 & 1.9 & 1.9 & - \\
Prefer not to say & 367 & 100.0 & 100.0 & 100.0 \\
Total & & & &
\end{tabular}


(82\%) were employed in paid, full-time positions, and $85.3 \%$ indicated that Uber operated in the city in which they lived. A total of $60.8 \%$ indicated that they had used Uber in the past and $30.6 \%$ indicated that they used Uber once per month or more. Nearly all the respondents (85\%) owned a car.

When asked to explain why they used Uber, the majority indicated that it allowed them to enjoy a drink without a concern for having to drive afterwards. Other reasons for using Uber included Uber's convenience when travelling, not having to drive, finding parking and the convenience associated with Uber.

The frequency of use of Uber was used to determine differences between the variables. Users were recoded into two groups, namely frequent (once or more per month) or seldom users (those who use Uber less often). Table 3 reports on differences in scores between frequent and seldom users. The null hypothesis of the test is equal means for the two groups. Table 3 reports on the probability of the $t$-test. While all reported probabilities are below 0.01 (or 1\%), the null hypothesis is rejected and the mean values of the two groups (regular and seldom users) are deemed to be statistically significant. Even though only the probability of the $t$-test is reported, results from three alternative tests (Satterthwaite-Welch $t$-test, ANOVA F-test, Welch F-test) confirm the significant difference in means - in some cases even at a lower probability as the reported $t$-test.

Frequent users of Uber had statistically significantly higher mean scores on all dimensions, as reflected in Table 3. The explanation for this can be associated with the previous use

TABLE 3: Differences between frequent and seldom users of Uber.

\begin{tabular}{llcccc}
\hline Dimension & Group & Mean & SD & $d f$ & $p$ \\
\hline PU & Seldom & 4.40 & 1.087 & 365 & 0.000 \\
& Frequent & 5.11 & 0.830 & - & - \\
PEU & Seldom & 4.66 & 1.124 & 365 & 0.000 \\
& Frequent & 5.31 & 0.751 & - & - \\
\multirow{2}{*}{ ATT } & Seldom & 4.65 & 0.933 & 365 & 0.000 \\
& Frequent & 5.31 & 0.835 & - & - \\
\multirow{2}{*}{ SN } & Seldom & 4.04 & 1.083 & 365 & 0.006 \\
& Frequent & 4.36 & 0.931 & - & - \\
\multirow{2}{*}{ PBC } & Seldom & 4.46 & 0.967 & 364 & 0.000 \\
& Frequent & 5.07 & 0.787 & - & - \\
\multirow{2}{*}{ Intention } & Seldom & 4.89 & 0.968 & 360 & 0.000 \\
& Frequent & 5.45 & 0.659 & - & - \\
\hline
\end{tabular}

SD, standard deviation; $d f$, degrees of freedom; ATT, attitude; PU, perceived usefulness; PEU, perceived ease of use; SN, subjective norm; PBC, perceived behavioural control. of Uber, which has influenced the respondents' future usage intention. Even though the mean differences are significant for all six indicators, the biggest difference is for PU, where the regular users rank it much higher than the seldom users, followed by attitude. The smallest difference between the two groups is for $\mathrm{SN}$. This is an indication that social pressure to use Uber, although significantly different for the two groups, is less of an issue compared to the individual contributes linked to the other five constructs.

\section{Reliability and descriptive statistics}

Initially, descriptive statistics were computed, specifically the mean and standard deviation for each item and dimension (Pallant 2016).

The descriptive statistics on each item appear in Appendix 1. From this, it is evident that the majority of respondents were positive towards Uber (with mean scores exceeding 4.00) on the items. However, items regarding the financial benefits of using Uber and items relating to the influence of others (the $\mathrm{SN}$ ) all had scores below 4.00 .

The mean scores on each dimension exceeded 4, with Intention and PEU having the highest mean scores, namely 5.066 and 4.863, respectively. By contrast, the SN had the lowest mean, namely 4.139 . This is somewhat surprising as while there is some influence of other people on the intention to use Uber; this was not as high as expected based on the scores on the other dimensions and some previous research (Chen et al. 2007).

The reliability of the dimensions in the instrument exceeds a Cronbach's Alpha of 0.8, which is preferable (Pallant 2016) and similar to previous studies (see Table 1).

The Pearson correlations are also presented in Table 4. The positive relationship between these variables in most instances exceeded 0.5, which indicates the presence of a strong relationship (Pallant 2016).

The variance inflation factor (VIF) scores of the dimensions were also examined to ensure there was no multicollinearity between the constructs (Hair et al. 2017).

Convergent reliability was assessed based on the Average Variance Extracted (AVE) score, with all scores exceeding 0.50 (Hair et al. 2017). Discriminant validity was assessed

TABLE 4: Descriptive, reliability and correlation statistics.

\begin{tabular}{|c|c|c|c|c|c|c|c|c|c|c|c|}
\hline Dimension & Mean & $\begin{array}{l}\text { Standard } \\
\text { deviation }\end{array}$ & Reliability & (1) & (2) & (3) & (4) & (5) & (6) & AVE & $\begin{array}{c}\text { Fornell-Larcker } \\
\text { Criterion }\end{array}$ \\
\hline PU (1) & 4.618 & 1.067 & $\alpha=0.918$ & - & - & - & - & - & - & 0.719 & 0.847 \\
\hline PEU (2) & 4.863 & 1.066 & $\alpha=0.959$ & $0.665^{* *}$ & - & - & - & - & - & 0.860 & 0.927 \\
\hline ATT (3) & 4.788 & 0.969 & $\alpha=0.908$ & $0.827^{* *}$ & $0.573^{* *}$ & - & - & - & - & 0.707 & 0.841 \\
\hline SN (4) & 4.139 & 1.048 & $\alpha=0.820$ & $0.561 * *$ & $0.311^{* *}$ & $0.525^{* *}$ & - & - & - & 0.544 & 0.738 \\
\hline PBC (5) & 4.645 & 0.956 & $\alpha=0.920$ & $0.726^{* *}$ & $0.726^{* *}$ & $0.731^{* *}$ & $0.478^{* *}$ & - & - & 0.641 & 0.800 \\
\hline Intention (6) & 5.066 & 0.920 & $\alpha=0.899$ & $0.697^{* *}$ & $0.572^{* *}$ & $0.758^{* *}$ & $0.517^{* *}$ & $0.737^{* *}$ & - & 0.792 & 0.890 \\
\hline
\end{tabular}

AVE, average variance extracted; ATT, attitude; PU, perceived usefulness; PEU, perceived ease of use; SN, subjective norm; PBC, perceived behavioural control.

**, indicates $5 \%$ level of significance. 
using the Fornell-Larcker Criterion, with all the square root of each construct being larger than the correlation with the other constructs (Hair et al. 2017), thereby fulfilling this criterium. Details are presented in Table 4.

\section{Hypothesis testing}

Model 1: Technology Acceptance Model: To test these hypotheses, a multiple regression was used to assess the extent to which PU and PEU predicted attitude and intention. An analysis was conducted to ensure no violations of normality, linearity or multicollinearity as well as homoscedasticity. Using the Enter method, it was found that PU and PEU explain a significant amount of the variance in the attitude (F2.364 = $\left.402.9, p<0.000, R^{2}=0.689, R_{\text {adjusted }}^{2}=0.687\right)$. The analysis reveals that both PU $(b=0.764, t(366)=19.517, p<0.000)$ and PEU $(b=$ $0.094, t(366)=2.409, p<0.017)$ significantly affected the attitude towards Uber. Both the PU of the app and the PEU contribute to the overall positive attitude towards Uber, but the major contributor to the attitude was the PU. Perceived ease of use also impacts PU $(b=0.665, \mathrm{~F} 1.361=289.7, p<0.000)$. With respect to intentions to use Uber, the contribution of PU can be seen $\left(b=0.697, \mathrm{~F} 1.361=340.2, p<0.000, R^{2}=0.486, R_{\text {adjusted }}^{2}=\right.$ $0.484)$.

Model 2: Theory of Planned Behaviour: To test the model, a multiple regression was used. This was performed to determine the extent to which attitude towards the behaviour, the SN and PCB influence the intention to use Uber. An analysis was conducted to ensure no violations of normality, linearity or multicollinearity as well as homoscedasticity. Using the Enter method, it was found that all three components account for a significant part of the intention to use Uber $\left(\mathrm{F} 3.361=227.8, p<0.000, R^{2}=0.656, R_{\text {adjusted }}^{2}=0.653\right)$.

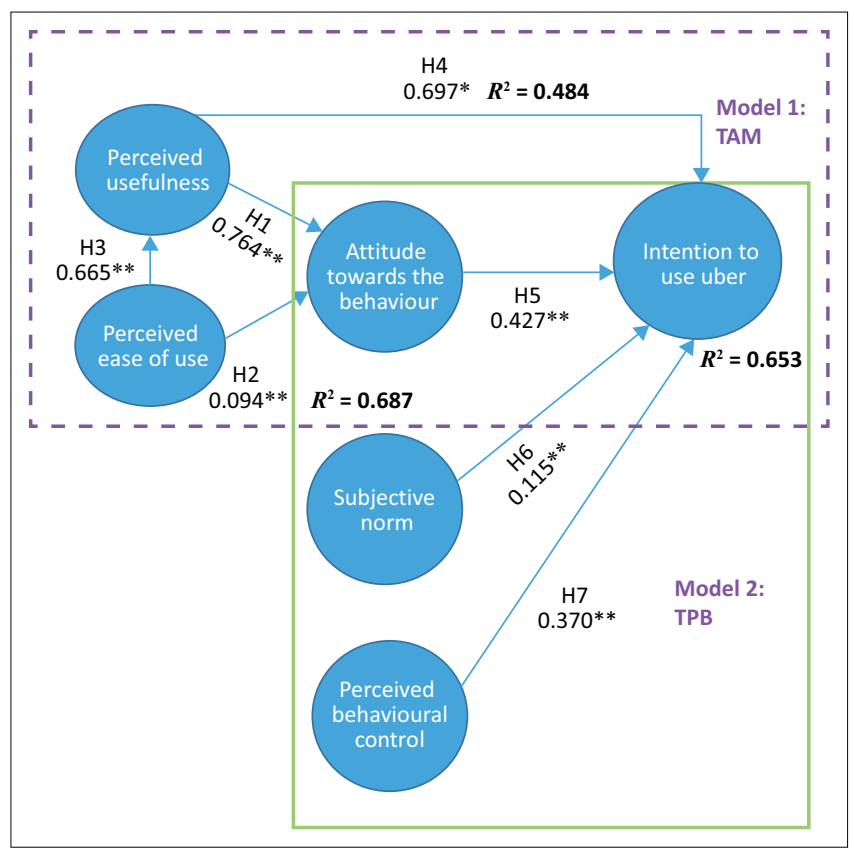

TAM, Technology Acceptance Model; TPB, Theory of Planned Behaviour. **, indicates $5 \%$ level of significance.

FIGURE 2: Model results.
The analysis reveals that attitude $(b=0.427, t(361)=8.987$, $p<0.000)$, SN $(b=0.115, t(361)=3.123, p<0.002)$ and PBC $(b=0.370, t(366)=8.046, p<0.000)$ significantly affected the intention of using Uber. While all contributed, the largest effects were seen in the attitude and PCB determinants. While the SN was statistically significant, its effect on intention is not as large. The findings from the multiple regression for both models are summarised in Figure 2. From these findings, all the hypotheses formulated for the study are supported (see Table 5).

Dealing with cross-sectional data, there is a distinct possibility that heteroscedasticity is present in both Models 1 and 2. We performed the White Test to confirm our expectation of the presence of heteroskedasticity. The White Test's results confirmed the presence of heteroskedasticity. We reestimated Models 1 and 2 with various corrections for heteroskedasticity. Tables 6 and 7 report the results for these adjusted models.

Table 7 reflects only minor differences in the level of statistical significance of the PEU variable compared to the unadjusted Model 1 results - reported in Figure 2. The variable remains statistically significant at the $10 \%$ level of significance. The signs and magnitude of the coefficients did not change significantly as a result of controlling for heteroskedasticity.

TABLE 5: Hypothesis testing. Model 1 - Technology Acceptance Model (TAM).

\begin{tabular}{lll}
\hline Hypothesis & \multicolumn{1}{c}{ Description } & Result \\
\hline H1 & $\begin{array}{l}\text { PU has a significant positive effect on the attitude } \\
\text { towards using Uber }\end{array}$ & Supported \\
H2 & $\begin{array}{l}\text { PEU has a positive effect on the attitude towards } \\
\text { Using Uber }\end{array}$ & Supported \\
H3 & PEU has a positive effect on the PU of Uber & Supported \\
H4 & PU has a positive effect on the intention to use Uber & Supported \\
H5 & $\begin{array}{l}\text { Attitude has a significant positive effect on the } \\
\text { intention to use Uber }\end{array}$ & Supported \\
H6 & SN has a positive effect on the intention to use Uber & Supported \\
H7 & PBC positively influences the intention to use Uber & Supported
\end{tabular}

PU, perceived usefulness; PEU, perceived ease of use; SN, subjective norm; PBC, perceived behavioural control.

TABLE 6: Model 1 - Regression analysis with Bartlett-Kernel, Newey-West adjustments for heteroskedasticity.

\begin{tabular}{lccc}
\hline Independent variable & Coefficient & $t$-Statistic & Prob. \\
\hline PU & 0.694299 & 14.34855 & 0.0000 \\
PEU & 0.085747 & 1.652739 & 0.0992 \\
C & 1.164902 & 5.423161 & 0.0000 \\
Adjusted $R^{2}$ & 0.687122 & - & - \\
F-statistic & 402.8921 & - & - \\
\hline
\end{tabular}

PU, perceived usefulness; PEU, perceived ease of use.

Dependent Variable: ATT.

TABLE 7: Model 2 - Regression analysis with Bartlett-Kernel, Newey-West adjustments for heteroskedasticity (Dependent Variable: Intentions).

\begin{tabular}{lccc}
\hline Independent variable & Coefficient & $\boldsymbol{t}$-Statistic & Prob. \\
\hline ATT & 0.411462 & 7.502223 & 0.0000 \\
SN & 0.104228 & 2.973675 & 0.0031 \\
PBC & 0.353057 & 5.679882 & 0.0000 \\
C & 1.017741 & 6.153081 & 0.0000 \\
Adjusted $R^{2}$ & 0.652573 & - & - \\
F-statistic & 227.0220 & - & - \\
\hline
\end{tabular}

ATT, attitude; SN, subjective norm; PBC, perceived behavioural control. 
Controlling for heteroskedasticity in Model 2 did not change the signs, coefficient or the statistical significance of the variables in the model.

The above multiple regressions are a standard and respected multiple variate analysis techniques, but which can be somewhat limiting. Other techniques may be more suited to account for measurement error as well as the simultaneous influence of all the variables included in the model. Structural equation modelling is an option as well as nesting Model 1 into Model 2, as this would provide more statistical insight into the role played by different constructs. To refine our econometric analysis, we therefore use Two-Stage Least Squares (2SLS) to nest Model 1 into Model 2. In this approach, attitude depends on PEU and the PU. The results are presented in Table 8.

\section{Discussion and recommendations}

The purpose of the study was to investigate the intention of South Africans to use Uber. As an app-based service, Uber is influenced not only by the attitude towards the app (Model 1: TAM) but also other factors, such as attitude toward the service, $\mathrm{SN}$ and PBC (Model 2: TPB).

In the case of Model 1, the PU and PEU both contribute to the development of the attitude towards Uber with PU making a direct contribution. This concurs with the findings of Chen et al. (2007) and Yang (2013). Perceived ease of use was also found to affect PU, but the findings differ from Chen et al. (2007) and $\mathrm{Wu}$ and Chen (2005) in regard to significance. In this study, PU was found to be significant regarding the intention to use Uber (but not on the use of electronic tolling or online tax). Perceived ease of use has a limited though significant effect on attitudes, but an indirect effect can also be observed. Conflicting findings regarding the TAM components have been found previously (Averweg 2008), and this study expands the TAM into CC, which can also explain the different findings. Thus, these findings suggest that the app required to access the service provides value based on its functioning and composition.

From Model 2, attitude, SN and PBC were found to significantly influence intention, which supports the findings of previous research (Al-Gahtani et al. 2007; Bhattacherjee 2000; Chen et al. 2007; Giles et al. 2004; Oliveira et al. 2020). This contrasts with the findings of $\mathrm{Wu}$ and Chen (2005) and Taylor and Todd (1995), which can be ascribed to different

TABLE 8: Two-stage least squares - Regression analysis with Bartlett-Kernel, Newey-West adjustments for heteroskedasticity (Dependent Variable: Intentions).

\begin{tabular}{lccc}
\hline Variable & Coefficient & $t$-Statistic & Prob. \\
\hline C & 0.907952 & 4.250902 & 0.0000 \\
ATT & 0.351122 & 3.416587 & 0.0007 \\
SN & 0.140385 & 1.011245 & 0.3126 \\
PBC & 0.406764 & 3.603955 & 0.0004 \\
$R^{2}$ & 0.652353 & - & - \\
F-statistic & 207.6152 & - & - \\
\hline
\end{tabular}

ATT, attitude; SN, subjective norm; PBC, perceived behavioural control. contexts; it also contrasts with Yang (2013), who found that the influence of $\mathrm{SN}$ was not significant.

Perceived usefulness, attitude and PBC had the largest impact on the intention to use Uber, emphasising their importance in CC. Thus, while the opinions of other people (such as family and friends) influence the intention to use Uber, the most important aspects are the attitude itself (linked to PU) and the extent to which the individual perceives their resources and skills in accessing the service. This result is also seen in the reasons given by respondents as to why they use Uber, which included convenience, not feeling like driving and enjoying a night out. The influence of others (as reflected in $\mathrm{SN}$ ) was not as high as had been suggested in previous studies, where it was the second most important factor in electronic tolling (Chen et al. 2007), and where it has a large effect on the intention in the case of electronic brokerages (Bhattacherjee 2000).

The frequency of use could affect the above empirical results. From the sample, 138 respondents used Uber only once, while 227 used Uber more than once. Estimating Model 2 for these differentiated groups revealed that $\mathrm{SN}$ was no longer statistically significant among the respondents who used it more than once. This can be because social pressure and the opinions of other people no longer play a role in the intention to use Uber among the regular Uber customers.

Various managerial implications are associated with the study for Uber, CC services and for the wider economy. For Uber, firstly, the importance of the Uber app, specifically its usefulness, can be seen in this study in the effect of the app on attitudes and intention to use Uber. Continuous development of the app is needed to ensure that it remains relevant to customers, is easy to use and can deliver value. Continued communication about the app, its functionality and the costs associated with the service needs to occur. Secondly, the app results in the development of positive attitudes to use Uber, which in turn influences the intention to use in the future, which impacts demand for the service. It can indicate a future need for drivers and vehicles that Uber will need to support. Thirdly, those respondents who had frequent usage of Uber had an increased likelihood of future usage. Turning this intention into actual behaviour and increasing their own usage of Uber can be a focus of Uber's marketing efforts, encouraging drivers to provide excellent service. This could be done using various types of promotions (discounts, coupons or referrals) to stimulate trial. Fourthly, the influence of others is identified in this study, thus encouraging users to recommend Uber through positive word-of-mouth.

For CC services, previous positive experiences with Uber can impact the adoption of existing services (e.g. Airbnb) and CC new services such as clothing rental subscription services (Piontek, Amasawa \& Kimita 2020) and furniture rental services (Kapoor \& Vij 2021). 
For the wider community, there are other implications that can be identified. Collaborative consumption, and specifically Uber impacts the broader economy and services offered (Zervas et al. 2017). For example, increased use of Uber impacts traffic congestion in urban areas, the availability of and access to collection points and the potential entry opportunities for present and future competitors.

There are various limitations associated with the study. Among the respondents, 138 respondents used Uber only once and their limited experience with Uber could impact their responses. Further, the disadvantages typically associated with the use of panel respondents, such as potential bias among respondents who take part due to their interest in the category can also be identified. The survey was distributed electronically, as this was suitable for the study, but this has the potential to impact the generalisability of the findings.

Further research is needed to compare these findings across a broader spectrum of respondents and cultures as well as to investigate the link between intention and behaviour in the context of CC. Trust is integral to CC, which has not been addressed in this study, and hence, the role of trust within CC also requires investigation. Another area for future research within the trust domain is the gender dimension of Uber use in South Africa. There are very few female Uber drivers in South Africa. Yet, according to Williams (2018), female Uber users prefer female drivers. This aspect must be investigated beyond the anecdotal, thereby increasing the attractiveness of these services (Hossain 2020). Investigation in other countries and among other consumer groups, including the use of qualitative methods is also suggested.

\section{Conclusion}

The purpose of this research was to investigate the intention of South Africans to use and engage in CC, specifically Uber. The findings show a positive attitude towards using this form of CC and that this positive attitude is influenced by the usefulness of the Uber app and its ease of use (PEU), though in an indirect manner. The intention to use the service is impacted by attitudes, PBC and SNs, though to a greater extent by the former two determinants. This study reflects the intention to engage in CC such as Uber in the future, and these positive findings suggest opportunities for organisations providing similar CC services.

\section{Acknowledgements}

\section{Competing interests}

The authors declare that they have no financial or personal relationships that may have inappropriately influenced them in writing this article.

\section{Authors' contributions}

All authors meet the criteria for authorship and contributed to the research and manuscript. A.B. was the project leader. A.B. was responsible for questionnaire design and survey. A.P. and D.B. provided the South African context and literature as conceptual contributions. A.P. performed data analysis. All three authors contributed to the writing and rewriting of the article as well the technical finalisation.

\section{Funding information}

The authors received no financial support for the research, authorship and/or publication of this article.

\section{Data availability}

The data that support the findings of this study are available from the corresponding author, D.B., upon reasonable request.

\section{Disclaimer}

The views and opinions expressed in this article are those of the authors and do not necessarily reflect the official policy or position of any affiliated agency of the authors and the publishers.

\section{References}

Ajzen, I., 1985, 'From intentions to actions: A theory of planned behavior', in J. Kuhl \& J. Beckmann (eds.), Action control: From cognition to behavior, pp. 11-39, Springer, Heidelberg.

Ajzen, I., 1987, 'Attitudes, traits, and actions: Dispositional prediction of behavior in personality and social psychology', Advances in Experimental Social Psychology 20, 1-63.

Ajzen, I., 1991, 'The theory of planned behavior', Organizational Behavior and Human Decision Processes 50(2), 179-211. https://doi.org/10.1016/0749-5978(91)90020-t

Ajzen, I., 2011, 'The theory of planned behaviour: Reactions and reflections', Psychology \& Health 26(9), 1113-1127. https://doi.org/10.1080/08870446.2011.613995

Ajzen, I. \& Fishbein, M., 2005, 'The Influence of Attitudes on Behavior', in Albarracín, D., Johnson, B.T. \& Zanna, M.P. (eds.), The Handbook of Attitudes, pp. 173-221, Lawrence Erlbaum Associates Publishers, Mahwah, NJ, USA.

Akoob, R., 2017, Uber will 'burn' if it continues to run, say metered taxi drivers, viewed 23 March 2017, from https://mg.co.za/article/2017-03-10-uber-will-burn-if-itcontinues-to-run-say-metered-axi-drivers

Al-Gahtani, S.S., Hubona, G.S. \& Wang, J., 2007, 'Information technology (IT) in Saudi Arabia: Culture and the acceptance and use of IT', Information \& Management 44(8), 681-691. https://doi.org/10.1016/j.im.2007.09.002

Al-Maghrabi, T., Dennis, C. \& Vaux Halliday, S., 2011, 'Antecedents of continuance intentions towards e-shopping: The case of Saudi Arabia', Journal of Enterprise Information Management 24(1), 85-111. https://doi.org/10.1108/174103911 11097447

Alam, S.S. \& Sayuti, N.M., 2011, 'Applying the Theory of Planned Behavior (TPB) in halal food purchasing', International Journal of Commerce and Management 21(1), 8-20. https://doi.org/10.1108/10569211111111676

Averweg, U.R., 2008, 'Information technology acceptance in South Africa: An investigation of perceived usefulness, perceived ease of use, and actual system use constructs', The African Journal of Information Systems 1(1), 44-66.

Babin, B.J. \& Zikmund, W.G., 2015, Exploring marketing research, Cengage Learning, Boston, MA.

Belk, R., 2007, 'Why not share rather than own?', The Annals of the American Academy of Political and Social Science 611(1), 126-140. https://doi. org/10.1177/0002716206298483

Belk, R., 2010, 'Sharing', Journal of Consumer Research 36(5), 715-734. https://doi. org/10.1086/612649

Belk, R., 2013, 'Extended self in a digital world', Journal of Consumer Research 40(3), 477-500. https://doi.org/10.1086/671052

Belk, R., 2014, 'You are what you can access: Sharing and collaborative consumption online', Journal of Business Research 67(8), 1595-1600. https://doi.org/10.1016/j. jbusres.2013.10.001

Bhattacherjee, A., 2000, 'Acceptance of e-commerce services: The case of electronic brokerages', IEEE Transactions on Systems, Man and Cybernetics, Part A: Systems and Humans 30(4), 411-420. https://doi.org/10.1109/3468.852435

Botsman, R. \& Rogers, R., 2011, What's mine is yours: how collaborative consumption is changing the way we live, Collins, London. 
Bouwman, H., \& Van De Wijngaert, L., 2009, 'Coppers context, and conjoints: A reassessment of TAM', Journal of Information Technology 24(2), 186-201. https:// doi.org/10.1057/jit.2008.36

Cheah, I., Shimul, A.S., Liang, J. \& Phau, I., 2020, 'Consumer attitude and intention toward ridesharing', Journal of Strategic Marketing 1-22. https://doi.org/10.1080/ 0965254X.2020.1733050

Chen, C.-D., Fan, Y.-W. \& Farn, C.-K., 2007, 'Predicting electronic toll collection service adoption: An integration of the Technology Acceptance Model and the theory of planned behavior', Transportation Research Part C: Emerging Technologies 15(5) 300-311. https://doi.org/10.1016/j.trc.2007.04.004

Chen, M.-F., 2007, 'Consumer attitudes and purchase intentions in relation to organic foods in Taiwan: Moderating effects of food-related personality traits', Food Quality and Preference 18(7), 1008-1021. https://doi.org/10.1016/j.foodqual.2007.04.004

Chomeya, R., 2010, 'Quality of psychology test between Likert scale 5 and 6 points', Journal of Social Sciences 6(3), 399-403. https://doi.org/10.3844/jssp.2010.399.403

Davidson, A., Habibi, M.R. \& Laroche, M., 2018, 'Materialism and the sharing economy: A cross-cultural study of American and Indian consumers', Journal of Business Research 82, 364-372.

Davis, F.D., 1989, 'Perceived usefulness, perceived ease of use, and user acceptance of information technology', MIS Quarterly 13(3), 319-340. https:// doi.org/10.2307/249008

Fishbein, M.E. \& Ajzen, I., 1975, Belief, attitude, intention and behavior: An introduction to theory and research, Addison-Wesley, Reading, MA.

Francis, J., Eccles, M.P., Johnston, M., Walker, A., Grimshaw, J., Foy, R. et al., 2004 Constructing questionnaires based on the Theory of Planned Behaviour: A manual for health services researchers, viewed on 14 September 2017, from http:// for health services researchers, viewed
openaccess.city.ac.uk/id/eprint/1735

Giddy, J.K., 2019, 'The influence of e-hailing apps on urban mobilities in South Africa', African Geographical Review 38(3), 227-239. https://doi.org/10.1080/19376812. 2019.1589732

Giles, M., McClenahan, C., Cairns, E. \& Mallet, J., 2004, 'An application of the Theory of Planned Behaviour to blood donation: the importance of self-efficacy', Health Education Research 19(4), 380-391. https://doi.org/10.1093/her/cyg063

Hair, J.F., Hult, G.T.M., Ringle, C. \& Sarstedt, M., 2017, A primer on partial least squares structural equation modeling (PLS-SEM), Sage, Los Angeles, CA

Hamari, J., Sjöklint, M. \& Ukkonen, A., 2016, 'The sharing economy: Why people participate in collaborative consumption', Journal of the Association for Information Science and Technology 67(9), 2047-2059. https://doi.org/10.1002/ asi.23552

Hamilton, B. \& Terblanche-Smit, M., 2018, 'Consumer intention to purchase green vehicles in the South African market: A Theory of Planned Behaviour perspective', South African Journal of Business Management 49(1), 1-7. https://doi.org/10.4102/ sajbm.v49i1.190

Henama, U.S. \& Sifolo, P.P.S., 2017, 'Uber: The South Africa experience', African Journal of Hospitality, Tourism and Leisure 6(2), 1-10.

Hossain, M., 2020, 'Sharing economy: A comprehensive literature review', International Journal of Hospitality Management 87, 102470.

Kapoor, A.P. \& Vij, M., 2021, 'Want it, rent it: Exploring attributes leading to conversion for online furniture rental platforms', Journal of Theoretical and Applied Electronic Commerce Research 16(2), 188-207.

Kaye, S.-A., Lewis, I., Buckley, L. \& Rakotonirainy, A., 2020, 'Assessing the feasibility of the Theory of Planned Behaviour in predicting drivers' intentions to operat conditional and full automated vehicles', Transportation Research Part F: Traffic Psychology and Behaviour 74, 173-183.

Kim, B., 2010, 'An empirical investigation of mobile data service continuance: Incorporating the theory of planned behavior into the expectation-confirmation model', Expert Systems With Applications 37(10), 7033-7039. https://doi. org/10.1016/j.eswa.2010.03.015

Laurell, C. \& Sandström, C., 2017, 'The sharing economy in social media: Analyzing tensions between market and non-market logics', Technological Forecasting and Social Change 125, 58-65. https://doi.org/10.1016/j.techfore.2017.05.038

Lee, W., Xiong, L. \& Hu, C., 2012, 'The effect of Facebook users' arousal and valence on intention to go to the festival: Applying an extension of the Technology Acceptance Model', International Journal of Hospitality Management 31(3), 819-827. https:// doi.org/10.1016/j.ijhm.2011.09.018

Liu, X., Wang, C., Shishime, T. \& Fujitsuka, T., 2012, 'Sustainable consumption: Green purchasing behaviours of urban residents in China', Sustainable Development purchasing behaviours of urban residents in Chir
20(4), 293-308. https://doi.org/10.1002/sd.484

Mathieson, K., 1991, 'Predicting user intentions: Comparing the Technology Acceptance Model with the theory of planned behavior', Information Systems Research 2(3) 173-191. https://doi.org/10.1287/isre.2.3.173

Maziriri, E., Mapuranga, M., Mushwana, J. \& Madinga, N., 2020, 'Antecedents that influence the intention to use the Uber mobile application: Customer perspectives in South Africa', International Journal of Interactive Mobile Technologies 14(8), 76-96. https://doi.org/10.3991/ijim.v14i08.10632

Möhlmann, M., 2015, 'Collaborative consumption: determinants of satisfaction and the likelihood of using a sharing economy option again', Journal of Consumer Behaviour 14(3), 193-207. https://doi.org/10.1002/cb.1512
Natarajan, T., Balasubramanian, S.A. \& Kasilingam, D.L., 2017, 'Understanding the intention to use mobile shopping applications and its influence on price sensitivity', Journal of Retailing and Consumer Services 37, 8-22.

Naughton, K., 2016, Ride-sharing service to have little impact on car sales: Survey, viewed 30 January 2017, from https://www.bloomberg.com/news/articles/2016-03-10/ ride-sharing-services-to.-have-little-impact-on-car-sales-survey

Nysveen, H., Pedersen, P.E. \& Thorbjørnsen, H., 2005, 'Intentions to use mobile services: Antecedents and cross-service comparisons', Journal of the Academy of Marketing Science 33(3), 330-346. https://doi.org/10.1177/0092070305276149

Oliveira, T., Tomar, S. \& Tam, C., 2020, 'Evaluating collaborative consumption platforms from a consumer perspective', Journal of Cleaner Production 273, 123018.

Orabi, R., 2019, 'Studying the effect of a sharing economy on the tourism industry: Developing the local economy for the Nubian Community', African Journal of Hospitality, Tourism and Leisure 8(5), 1-21.

Pallant, J., 2016, SPSS survival manual: A step by step guide to data analysis using IBM SPSS, 6th edn., Open University Press, McGraw-Hill, Maidenhead.

Piontek, F.M., Amasawa, E. \& Kimita, K., 2020, 'Environmental implication of casual wear rental services: Case of Japan and Germany', Procedia CIRP 90, 724-729.

PricewaterhouseCoopers, 2015, The sharing economy, Consumer Intelligence Series, viewed 05 May 2017, from https://www.pwc.com/us/en/technology/publications/ assets/pwc-consumer-intelligence-series-the-sharing-economy.pdf

Segev, L., 2015, The Uber way, viewed 14 September 2017, from http://www.itweb. co.za/index.php?option=com content\&view=article\&id $=144232$

Sheeran, P., 2002, 'Intention-behavior relations: A conceptual and empirical review', European Review of Social Psychology: European Review of Social Psychology 12(1), 1-36. https://doi.org/10.1080/14792772143000003

Shereni, N.C., 2019, 'The tourism sharing economy and sustainability in developing countries: Contribution to SDGs in the hospitality sector', African Journal of Hospitality, Tourism and Leisure 8(5), 1-10.

Sodha, S., 2017, 'Uber is smart, simple and seductive. But should we still be using it?', The Guardian, 05 March 2017, viewed on 22 June 2021, from https://www. theguardian.com/commentisfree/2017/mar/05/am-i-being-uber-touchy-ethicsminicab-app

Solomon, M.R., Bamossy, G.J., Askegaard, S. \& Hogg, M.K., 2013, Consumer behaviour: A European perspective, 5th edn., Pearson Education, Harlow.

Spiegel, D., 2016, Uber's books still top secret but its biggest weakness isn't, viewed 23 March 2017, from http://www.cnbc.com/2016/06/08/ubers-66-billion-valuationmay-ride-on-shaky-foundation.html

Tarkiainen, A. \& Sundqvist, S., 2005, 'Subjective norms, attitudes and intentions of Finnish consumers in buying organic food', British Food Journal 107(11), 808-822.

Taylor, S. \& Todd, P.A., 1995, 'Understanding information technology usage: A test of competing models', Information Systems Research 6(2), 144-176. https://doi. org/10.1287/isre.6.2.144

Tussyadiah, I.P., 2015, 'An exploratory study on drivers and deterrents of collaborative consumption in travel', in I.P. Tussyadiah \& A. Inversini (eds.), Information and communication technologies in tourism 2015, pp. 817-830, Springer, Cham.

Uber, 2017, Uber in SA - The road so far, viewed 20 January 2017, from https://newsroom. uber.com/south-africa/uber-changing-the-way-sa-moves-one-ride-at-a-time

Van Der Westhuizen, J., 2007, 'Glitz, glamour and the gautrain: Mega-projects as political symbols', Politikon 34(3), 333-351. https://doi.org/10.1080/02589340801962650

Van Zyl, G., 2016, Cairo surpasses Joburg as Uber's biggest African city, viewed 30 January 2017, from http://www.fin24.com/Tech/News/cairo-surpasses-joburgas-ubers-biggest-african-city-20161123

Venkatesh, V., 2000, 'Determinants of perceived ease of use: integrating control, intrinsic motivation, and emotion into the Technology Acceptance Model', Information Systems Research 11(4), 342-365. https://doi.org/10.1287/isre.11.4.342.11872

Wallsten, S., 2015, 'The competitive effects of the sharing economy: How is Uber changing taxis?', Technology Policy Institute 22, 1-21.

Weatherhead, R., 2014, 'Say it quick, say it well - The attention span of a modern Internet consumer', The Guardian, 28 February, viewed 25 February 2021, from https://www.theguardian.com/media-network/media-network-blog/2012/ mar/19/attention-span-internet-consumer

Williams, C., 2018, 'I'd like a female driver please' - Would this improve our safety when we use Uber/Taxify?, viewed 22 July 2021, from https://www.news24.com/ w24/popculture/entertainment/technology/would-more-women-driversimprove-our-safety-in-ubertaxify-20180509

Wu, L. \& Chen, J.-L., 2005, 'An extension of trust and TAM model with TPB in the initial adoption of on-line tax: An empirical study', International Journal of HumanComputer Studies 62(6), 784-808. https://doi.org/10.1016/j.ijhcs.2005.03.003

Yang, H.C., 2013, 'Bon appétit for apps: Young American consumers' acceptance of mobile applications', Journal of Computer Information Systems 53(3), 85-96. https://doi.org/10.1080/08874417.2013.11645635

Zervas, G., Proserpio, D. \& Byers, J.W., 2017, 'The rise of the sharing economy: Estimating the impact of Airbnb on the hotel industry', Journal of Marketing Research 54(5), 687-705. https://doi.org/10.1509/jmr.15.0204 


\section{Appendix 1}

TABLE 1-A1: Descriptive statistics for the complete instrument.

\begin{tabular}{|c|c|c|c|}
\hline Construct & Items & Mean & SD \\
\hline \multirow[t]{6}{*}{ PU } & Uber is practical & 5.11 & 1.055 \\
\hline & Using Uber improves my life & 4.56 & 1.371 \\
\hline & Using Uber makes things more efficient & 4.84 & 1.201 \\
\hline & Using Uber improves my transport options & 5.00 & 1.191 \\
\hline & $\begin{array}{l}\text { Using Uber enables me to reach my destination } \\
\text { faster }\end{array}$ & 4.21 & 1.362 \\
\hline & Using Uber is beneficial for me financially & 3.97 & 1.378 \\
\hline \multirow[t]{5}{*}{ PEOU } & I think setting up the application is easy & 4.82 & 1.179 \\
\hline & I think it is easy to use the Uber application & 4.88 & 1.150 \\
\hline & I think the Uber app is user-friendly & 4.84 & 1.129 \\
\hline & The payment process for using Uber is effortless & 4.90 & 1.160 \\
\hline & Rating an Uber driver after the ride is easy & 4.87 & 1.130 \\
\hline \multirow[t]{6}{*}{ ATT } & I am positive towards Uber operating in my area & 5.02 & 1.140 \\
\hline & I think using Uber is a good idea & 5.15 & 1.001 \\
\hline & I think Uber serves a good purpose & 5.17 & 0.984 \\
\hline & I think I can save money using Uber & 4.11 & 1.373 \\
\hline & I think I can save time using Uber & 4.39 & 1.344 \\
\hline & I think using Uber is comfortable & 4.89 & 1.118 \\
\hline \multirow[t]{6}{*}{ SN } & I think my close friends use Uber & 4.80 & 1.250 \\
\hline & $\begin{array}{l}\text { It is important to me what my close friends think } \\
\text { about Uber }\end{array}$ & 3.75 & 1.595 \\
\hline & I think my close friends think I should use Uber & 3.99 & 1.495 \\
\hline & Public opinion about Uber is positive in general & 4.56 & 1.087 \\
\hline & $\begin{array}{l}\text { It is important to me what the public thinks } \\
\text { about Uber }\end{array}$ & 3.90 & 1.594 \\
\hline & $\begin{array}{l}\text { The media attention Uber receives affects my } \\
\text { willingness to use the service }\end{array}$ & 3.83 & 1.56 \\
\hline \multirow[t]{7}{*}{ PBC } & I have the resources to use Uber & 4.89 & 1.145 \\
\hline & I have the knowledge to use Uber & 4.99 & 1.123 \\
\hline & I have the ability to use Uber & 5.11 & 0.955 \\
\hline & I trust Uber's screening of their drivers & 4.31 & 1.284 \\
\hline & I trust the rating system of Uber & 4.42 & 1.169 \\
\hline & I feel in control when using Uber & 4.31 & 1.290 \\
\hline & $\begin{array}{l}\text { I feel safer using Uber than a standard taxi } \\
\text { service }\end{array}$ & 4.75 & 1.247 \\
\hline \multirow[t]{7}{*}{ Intention } & I intend to use Uber in the future & 5.02 & 1.178 \\
\hline & $\begin{array}{l}\text { I would consider using Uber the next time I need } \\
\text { a taxi service }\end{array}$ & 5.07 & 1.155 \\
\hline & $\begin{array}{l}\text { I would consider using Uber when visiting } \\
\text { another country }\end{array}$ & 4.99 & 1.096 \\
\hline & $\begin{array}{l}\text { I would consider using Uber when visiting } \\
\text { another city }\end{array}$ & 5.00 & 1.141 \\
\hline & $\begin{array}{l}\text { I would consider using Uber when having a night } \\
\text { out }\end{array}$ & 5.10 & 1.185 \\
\hline & I would consider using Uber with my friends & 5.15 & 1.068 \\
\hline & I would not use Uber if it was illegal & 5.13 & 1.321 \\
\hline
\end{tabular}

SD, standard deviation; PU, perceived usefulness; PEOU, perceived ease of use; ATT, attitude;

$\mathrm{SN}$, subjective norm; PBC, perceived behavioural control. 